\title{
Happiness Issue - Moral Aspects of its Biochemical Enhancement
}

\author{
Kwestia szczęścia - moralne aspekty jego biochemicznego wzmacniania
}

\author{
Zlatica Plašienková, Martin Farbák \\ Faculty of Arts, Comenius University in Bratislava, Slovakia \\ ORCID ZP https://orcid.org/0000-0003-3201-3722; MF https://orcid.org/0000-0003-1076-3338• zlatica.plasienkova@uniba.sk \\ Received: 24 Aug, 2021; Revised: 26 Sep, 2021; Accepted: 29 Sep, 2021
}

\begin{abstract}
The search for happiness is something that constitutes human existence from its beginning, and even though people have achieved unimaginable progress in science and technologies, they still have not found the secret of being happy. Transhumanist authors, headed by Mark Walker, believe we can reach happiness biochemically using specific drugs and without considerable side effects. They consider it to be our moral duty because it would increase the prosocial behaviour of people enhanced in that way, following research showing that the happier people are, the more useful it is for society. In this paper, we critically respond to the vision of biochemical enhanced happiness (bio-happiness). We follow the classic and modern authors in our analysis of what happiness is, and based on this analysis, we want to demonstrate why the biochemical enhancement of happiness is not a moral imperative these days. On the contrary, we offer the reasoning why such a vision of bio-happiness is not morally right, and why it bears the risk of losing the connection between happiness and finding the meaningfulness of life. We critically evaluate the absence of spirituality in the transhumanist understanding of man and the devaluation of her/his intrinsic values.
\end{abstract}

Keywords: man, happiness, bio-happiness, biochemical enhancement, transhumanism

Streszczenie: Poszukiwanie szczęścia jest czymś, co konstytuuje ludzką egzystencję od samego początku i choć ludzie osiągnęli niewyobrażalny postęp w nauce i technologii, wciąż nie odkryli sekretu bycia szczęśliwym. Autorzy transhumanistyczni, podzielający poglądy Marka Walkera, są przekonani, że można zwiększyć szczęście biochemicznie, stosując określone leki, bez znaczących negatywnych skutków ubocznych. Uważają to za moralny obowiązek, ponieważ zwiększyłoby to prospołeczne zachowania tak wzmocnionych ludzi. Potwierdzają to badania wykazujące, że szczęśliwsi ludzie są bardziej przydatni dla społeczeństwa. W tym artykule krytycznie odpowiadamy na wizję szczęścia wzmocnionego biochemicznie. Podążamy za klasycznymi i współczesnymi autorami w analizie tego, czym jest szczęście i dlaczego jego biochemiczne wzmocnienie nie jest moralnym imperatywem w dzisiejszych czasach. Wręcz przeciwnie, przedstawiamy uzasadnienie, dlaczego taka wizja bio-szczęścia nie jest moralnie słuszna i dlaczego niesie ryzyko utraty związku między szczęściem a odnalezieniem sensu życia. Krytycznie oceniamy brak duchowości w transhumanistycznym rozumieniu człowieka i dewaluację jego wewnętrznej wartości.

Słowa kluczowe: człowiek, szczęście, bio-szczęście, wzmocnienie biochemiczne, transhumanizm 


\section{Introduction}

A person can be healthy, wealthy, and loved, but that still does not mean she/he will be happy. On the contrary, some people are poor, ill, and not embraced by love, but despite that they are happy. Happiness is truly one of the most paradoxical aspects of human life. It is difficult to achieve, and even more so, to sustain it. It is an overarching phenomenon of many important life attributes, and even though we have not found the secret of happiness, there are already voices in academic discussion, which propose the enhancement of happiness, artificially. The question is if it is really morally necessary as some authors suggest and if it would not harm the authentic and autonomous way of experiencing happiness, which is deeply connected with finding the meaning of our existence.

In the search for happiness, people are sometimes willing to push moral boundaries, depending on the consideration of what it means. Even though there is no guaranteed way to reach real happiness, some people believe money could at least help, others invest energy into loving their loved ones, and some want to use specific psychotropic substances to reach happiness. Each of us feels the desire to improve her/his life conditions with childlike determination. Kids do not give up on changing more or less petty, unfavourable circumstances, but when they encounter an "insurmountable" obstacle, they have no choice, but need to change their attitude. Naturally, the human pursuit to achieve a happier life, seems to be our fundamental characteristic, together with a profound desire for happiness, but unlike children, adults bear a moral responsibility when they push the boundaries in their search for happiness. How far can biochemical enhancement of happiness push the limits of man's nature, and which ones should not be removed on the path towards the human future, if we want to prevent adverse moral consequences, whilst the most important question remains unanswered: What is happiness?
Although we are not able to answer this question within the short scope of this paper; we want to demonstrate why the biochemical enhancement of happiness is not morally right, and why it bears the risk of losing the connection between happiness and finding the meaningfulness of life. This connection is held together through the spiritual perception of one's existence. Therefore, we critically evaluate the absence of spirituality in the transhumanist understanding of man and in their vision of enhancing happiness. The transhumanist vision of bio-happiness reduces the apprehension of happiness as a psychological and social subject, with significant genetic conditionality. For the aims of our paper, we try to reflect these questions from a deeper philosophical point of view, which is missing in this transhumanist conception.

\section{Biochemical enhancement of happiness}

Happiness can be artificially enhanced in various ways. Since genetic enhancement is not yet allowed, the biochemical enhancement of happiness is at the centre of the discussion. In transhumanistic discourse, it is also referred to as bio-happiness. This is based on the assumption that happiness is determined, primarily biologically, and thus, can be regulated, improved, or induced by various external interventions. Thus, the concept of bio-happiness specifically represents happiness, enhanced biochemically (pharmacologically).

Artificial enhancement of happiness is not such a new phenomenon as it might seem. People have always been trying to ease their living, and the most notorious way of how to do it was through consumption of alcohol, coffee, tea, or cigarettes. However, nowadays, many people regularly consume chemical substances, similar to what could be called happiness pills. We do not talk only about the patients of psychologists and psychiatrists, but a considerable number of people 
use micro-dosing ${ }^{1}$ to raise their happiness levels every day. This kind of doping is already practised, and used drugs are related to amphetamines ${ }^{2}$, which raise the concentration of dopamine in the brain. We cannot forget to also mention users of hard drugs, whose physical and psychological addictions, potentially lead to death. Only a small number of people do not actually consume anything to raise their feeling of psychological comfort. In this sense, we are not far away from Huxley's Brave New World (Huxley 1932). However, is that the right path to finding true happiness and meaningfulness, or is it only the method of how to ease our dayto-day living?

Even though there are already many ways to artificially improve the level of good feelings, the most often thought connected with biochemical enhancement of happiness is the use of psychotropic substances, which will bring a person to an elevated state, accompanied by several negative side effects. ${ }^{3}$ However, the transhumanist vision of bio-happiness has little to do with such an idea. On the contrary, the main representative who defends the vision of biochemically improved happiness, Canadian American philosopher, Mark Walker, claims that it will lead to more active prosocial be-

1 Micro-dosing is the practice of consuming very low doses of psychedelic substances, such as lysergic acid diethylamide (LSD), psilocybin containing mushrooms or MDMA.

2 Good example of amphetamine in the transhumanist vision of human enhancement is the chemical substance, MDMA, better known as Ecstasy. Brian D. Earp and Julian Savulescu promoted MDMA as a chemical agent that could enhance loving relationships (Earp and Savulescu 2020).

3 The research shows that people usually connect the usage of chemical substances with negative side effects. For example, Australians were asked the following question: "If there was a legally available drug that could be bought over the counter, that made you feel happy, and did not have any side-effects, do you think there would be occasions when you would take it?" (Frey 2018, 42) Three quarters of the respondents said they would not consume a legally available happiness pill. haviour. Walker became a leading author in bio-happiness discourse with his book, Happy-People-Pills for All, since he offered a comprehensive transhumanist vision of the artificial enhancement of happiness (Walker 2013). In his manifesto, he openly claimed the unstable character of the word "happiness", and offered a simple, but correct explanation, that describes how broad is the usage of this word in the human language. He said: "There is a perfectly good sense in which you might describe your slightly intoxicated co-worker as «happy», but clearly this is not the intended usage, when parents say they «just want their children to be happy»" (Walker 2013, 41). Since the word happiness is so difficult to grasp, an American psychologist, Martin Seligman, even rejects its scientific use. He stated that the word happiness is "so overused that it has become almost meaningless. It is an unworkable term for science" (Seligman 2011, 9). We can agree with Walker and Seligman that the word happiness is hard to define, but we believe it should not discourage our discovering of its meaning in human life. The issue with defining happiness can be visible in the question we ask ourselves quite often: Am I happy? From our personal experience we can say we often do not consider ourselves happy, but nor do we claim to be unhappy. Most of us are somewhere in the middle of the happiness scale, because we expect it can be better at some point in our future. Therefore, the perception of happiness is clearly connected with the process of personal evolution and maturation, which will be discussed deeply in the next chapter.

Walker's understanding of happiness (that also represents the transhumanist interpretation) is a combination of happiness understood as a synonym for well-being, and happiness as a psychological term. Walker explained, he combined four monistic theories of happiness, whereas each is insufficient to capture what happiness is on its 
own. ${ }^{4}$ He joined the emotional and the cognitive elements of our psyches and argued for a composite view of happiness. He calls this composite understanding of happiness also "folk psychology" and says that: "Folk psychology divides our mental life into cognitive and emotional faculties, and folk psychology describes both of these, in terms of positive or negative valence. It seems likely that for most people, most of the time, these two co-vary" (Walker 2013, 67-68). He argues that psychological happiness is a part of well-being, but he emphasises there is more to well-being than happiness.

Even though Walker claimed to attempt the philosophical understanding of happiness in his work (Walker 2013, 16), we do not consider it to be fulfilled, since the main emphasis in his conception was put on the aspects of positive psychology. The psychological understanding of happiness fundamentally changed, only recently, when it became a subject of positive psychology, which is one of the youngest fields of psychology, and it has already been reflected in transhumanism. Similar to medicine, the psychological sciences were focused mainly on eliminating the negative aspects and manifestations of the human psyche. Positive psychology focuses its research on the positive things that increase the well-being and happiness of people and try to develop them. Martin Seligman and Mihaly Csikszentmihalyi, who are considered to be fathers of positive psychology, defined its main role in the journal, American Psychologist. They have predicted it will allow psychologists of the $21^{\text {st }}$ century to understand and support those features that allow individuals, communities, and societies to thrive. They believe the same methods that were used for healing, can be used "to measure, understand, and build those characteristics

4 It is "sensory hedonism" and "emotional state theory" which are affective theories of happiness. Another two are cognitive theories of happiness. It is the "whole life satisfaction view" and "attitudinal hedonism account of happiness" (Walker 2013, 43-48). that make life mostly worth living" (Seligman and Csikszentmihalyi 2000, 13). The transhumanist goal to biochemically enhance happiness, follows the direction of psychological sciences represented in positive psychology.

To complete the initial part of our critical reflection of biochemical enhancement of happiness, we cannot omit to mention moral arguments that are presented in this transhumanist vision. It follows the fact that within the entire spectrum of the human population, there are people with a tendency to depression on the one hand, and on the other hand, there are hyperthymic people, who represent an exceptional genetical mutation from normal. The brains of these people produce more serotonin than is common in most of the population, which is reflected in a consistently good mood, satisfaction, and greater resilience to negative aspects of life. The main goal of this vision is to make all members of society hyperthymic. Instead of genetic manipulation that would allow this, but is not yet available, transhumanists suggest a biochemical route. They believe pharmacological agents would increase serotonin and dopamine levels in the brain, without adverse side effects. Hypothetically, such a biochemical enhancement would benefit the whole society, thanks to the more intense prosocial behaviour of its citizens. Walker believes that with such an artificial increase of happiness in society, people would "achieve more in the workplace, have better relations with others, and have better health outcomes" (Walker 2013, 266). He also refers to studies that show that the increase in the intensity of happiness is accompanied by an increase in prosocial behaviour, which specifically represents any activities with a positive social impact, such as helping the homeless, collecting garbage in parks, educating the poor, and so on (Walker 2007, 96-97). The results of these studies can be summarised in the opinion: feeling good - acting right. This is presented as a main moral reason to pursue the biochemical enhancement 
of happiness. Happy-people-pills distributed to everybody for free, are supposed to address the root problem of humanity, which is a lack of goodwill. Altering our biology with happy-people-pills should, supposedly, have some positive effect in the fight for greater social justice.

It is important to put our focus on the basic premise of this vision, supported by its proponents - the human perception of happiness is genetically conditioned ${ }^{5}$ (Walker 2007, 100; Hughes 2004, 48; Pearce 1998). The authors emphasised that the circumstances of life alone and the psychology of happiness are not sufficient determinants (omitting the profound philosophical analysis). Explaining and defending the presented vision of bio-happiness is characterised by what connects almost all biochemical visions of human enhancement - their application on a healthy population. The chemicals that can have a truly positive impact on the treatment of mental illnesses or disorders are primarily analysed for use in the general population. By transhumanists, the governments should take over control and distribute happy-people-pills for free to every citizen. Walker emphasises that the use of biochemical enhancement is a moral duty (Walker 2013, 266). This is also the position of David Pearce, who, in his utilitarian manifesto; The Hedonistic Imperative, advocates that the chemical improvement of happiness should even be an explicitly formulated goal of democratic public policies (Pearce 1998).

In this part of our paper, we tried to present a transhumanist vision of the biochemical enhancement of happiness and how its proponents (headed by Mark Walker) understand its moral aspects. We also tried to explain the issue of defining the word "happiness", which makes its research more

5 The hope of discovering the gene of happiness is put into the genetic research of hyperthymic people. It is important to note that the exact causes of hyperthymia have not yet been determined. If it turns out to be the whole complex of genetic characteristics, it will not be easy to solve the genetic mystery of happiness. difficult, and we briefly indicated our critical standpoint, which will be extended in the next part.

\section{What is happiness and why it matters?}

To explain what happiness is and why it matters from the moral point of view, we have set three signs of happiness that are important for the aim of this paper and will be the subject of our further research. The first sign has been already recognised by philosophers of Ancient Greece, who made it clear that happiness is not the same thing as pleasure. They put the moral aspects of being happy, above the feeling of happiness itself. Aristotle suggested developing and cultivating our virtues, which can lead us to a blissful and happy life. He considered human desire for what is pleasant, to be insatiable and indiscriminate. In his opinion, the performed activity of this desire could strengthen the bad tendencies people are born with (Aristotle 2000, 1119b, 58). Epicurus answered the question about pleasures even more clearly, when he said: "Thus, every pleasure is a good by reason of its having a nature akin to our own, but not every pleasure is desirable. In like manner, every state of pain is an evil, but not all pains are uniformly to be rejected" (Epicurus 2013, 159). Contemporary philosophers, such as Louis Pojman and James Fieser, agree with Plato, who (according to them) suggested he would rather be moral than successful, because the most important thing is the harmony of the soul, which can be damaged by immoral actions. Being asked to choose between being morally good and immoral, is like being asked to choose between being healthy and sick (Pojman and Fieser 2011, 71). The cultivation of virtues, as a way of enhancing happiness, is standing contrary to artificial enhancement. ${ }^{6}$

The Austrian psychoanalyst and philosopher, Frankl, declared that desire for happiness is the most original and profound

6 This issue is reflected in the work of James $\mathrm{Hu}$ ghes After Happiness, Cyborg Virtue (Hughes 2011). 
desire of man. However, he pointed out (from his clinical practice) that focusing only on pleasure (or well-being), leads to losing the reason(s) for happiness. Turning away from happiness, means that a person forcibly turns to happiness alone, represented by pleasures (Frankl 1992, 680). We can conclude, following the mentioned philosophers, that one is happy or unhappy in exact proportion to one's moral integrity. It is the first condition of long-lasting happiness, and it is in contradiction with the transhumanist vision of bio-happiness. Taking the happy-people-pills does not affect our morality at all, and therefore, cannot make us happy, it just makes us feel better, which is accompanied by prosocial behaviour, and other beneficial effects, presented by Mark Walker as better work performance, better relationship, or better health. The moral reasons Mark Walker presented as proof of the moral correctness of biochemical enhancement of happiness have mainly extrinsic value and does not morally influence the inner personality of man.

The second sign of happiness is its deep connection with the spiritual side of human beings. We believe understanding the spiritual side of happiness can enable us to understand its paradoxical and relative character in a deeper way, and it can give us a holistic vision of what happiness is. Interdisciplinary research on happiness is led empirically by psychologists, sociologists, neuroscientists, economists, and political scientists. Bruno Frey pointed out it is a philosophy that can make a difference, because it deals with happiness, analytically, (Frey 2018, 3), and we can add holistically, too. From the named sciences, which research happiness, only philosophy includes spirituality in its research, too. Here we want to underline that philosophy does not examine spirituality in the same way as theology. Thaddeus Metz, a South-African philosopher, proved spirituality can be studied from the naturalistic perspective as well (Metz 2013, 35-36). Metz declares that spirituality accelerates the process, by which we find meaningfulness and happiness. But what exactly is the spirituality we are discussing? English philosopher, John Cottingham, answers this issue in his work: The Spiritual Dimension, where he expresses spirituality as a transformative power that is "capable of supplying a deficit in our fragmented and vulnerable human existence, and thus, rendering our lives incomparably richer and more meaningful than they would otherwise have been" (Cottingham 2005, 126). He defines it also as the tranquillity of mind - "the peace that passes all understanding", but not only as an escape strategy, but more specifically, as a peaceful mental state - acceptance, called by Greeks "ataraxia”. At its core, it results from something more important to be recognised "from a certain kind of awareness or focus", which Cottingham links with the reaching of life's meaningfulness and happiness (Cottingham 2003, 83 ). He argues that using drugs could dull our sensibilities (and mitigate our existential urge), but such an existence would quickly become bland and meaningless. In the same relevance with the biochemical enhancement of happiness, Thaddeus Metz states something similar: "being subjugated and manipulated while feeling upbeat because of psychotropic drugs, would not be a way for one's life to matter" (Metz 2013, 27). In his analysis, he concludes by identifying the primary conditions that determine the successful spiritual process of reaching meaningful life and happiness, amongst which, is authenticity and autonomy (Metz 2013, 29). We must point out that the chemical ways of enhancing happiness may disrupt awareness and focus (proposed by Cottingham), and consequently, also the authenticity and autonomy (proposed by Metz), which can have adverse consequences for achieving life's meaningfulness and happiness. Our conclusion is that spirituality is the gate to reach meaningfulness and happiness. Spirituality is what connects the experiencing of happiness and finding the meaning of life. In the transhumanist vision of bio-happiness, we have not 
found such a complex understanding of happiness. Happiness is understood, primarily, as something determined genetically, and has only extrinsic value as a utility for society rather than long-term intrinsic value for a person.

Now we need to answer the issue we have mentioned in the first part of this paper, and it is also the third sign of happiness that we want to present. The experiencing of happiness is a result of the process of personal evolution and maturation. This is very important, because it is connected with the moral growth we have already outlined, reflecting the first sign of happiness. We hold the position of Pierre Teilhard de Chardin that was outlined in his essay: Réflexions sur le Bonheur from 1943 (Teilhard de Chardin 1973, 119-140). He was optimistic about finding happiness. In comparison to the reductionist concept of well-being that was taken over by transhumanists from the positive psychology, Teilhard believed there are some universal characteristics of happiness. He was convinced that true happiness is the happiness of growth, even though it is challenged by sorrows. In his conception, happiness has neither existence nor value in itself, as an object which we can pursue. It is no more than the effect of appropriately directed action: a by-product of effort. As for Teilhard, it is wrong to suggest that some sort of renewal of ourselves (example of biochemical enhancement of happiness) is all that is needed for happiness. Something more is required, for no change brings happiness unless the way in which it is effected involves personal growth. The happy man is somebody who, without any intended search for happiness, finds it as an added bonus, in the act of attaining the entirety and finality of his own self. In the same context, Mike Martin, a Philosophy Professor at Chapman University, described the paradox of happiness. According to him, happiness is something that cannot be found intentionally. It is an achievement gained in the living of meaningful relationships and activities (Martin 2008, 171-184). We cannot be forced to be happy, or even to decide about it. Happiness requires freedom embodied in authentic and autonomous life. In this meaning, bio-happiness is not real happiness. Any kind of pill or body adjustment cannot make us truly happy in the long term. Even though the goal of "Happy-People-Pills" is not morally wrong on its own, it is used particularly as the utility for society, missing the intention of person's moral growth, which will turn against society in the long run. The artificial enhancement of happiness through biochemical agents is basically a mistaken search for real happiness.

\section{Conclusion}

There is no doubt that happiness is significantly important for human life, but at the same time, it is very difficult to define and explain it. Recent progress in science and technology has opened up new possibilities for achieving happiness, which can be found in the transhumanistic vision of biochemical enhancement of happiness. "Happy-People-Pills", which are supposed to guarantee the solution of many social problems, and help to achieve well-being for all people, are a tempting way that its proponents present as the moral imperative of these days. Such a mode of biochemical alteration of human biology should increase the goodwill of enhanced people, as well as the intensity of their prosocial behaviour. On the one hand, we appreciate the efforts of transhumanist authors to find a way to greater moral good through the artificial improvement of happiness, but on the other hand, we critically evaluate the standpoints on which they base their vision. We believe it would cross the moral limits, which may have adverse consequences for the future of humans.

We have also concluded that the vision of bio-happiness, bears the risk of losing the connection between happiness and finding the meaning of life, because such vision reduces a holistic philosophical understanding of man, and the way she/he acquires happiness. We are convinced that finding 
happiness is not only related to biological and psychological, but also to the spiritual dimension of man. Through the spiritual comprehension of human existence, we follow the path of personal evolution and maturation. On this path, we naturally encounter many obstacles, suffering and pain, which the "Happy-People-Pills" could ease or even remove from the short-term point of view, but their usage would disrupt the human ability to understand one's existence autonomously and authentically. In the long run, it disables personal evolution, moral maturation, and spiritual growth, which are determined by the cultivation of human intrinsic moral values. The human being enhanced this way, would lose the ability to discover the path to happiness and life's meaning; these are always just a by-product of appropriately directed action, and not the goal itself.

Author Contributions: Conceptualization, Z.P. and M.F.; Resources, Z.P. and M.F.; Writing - Original Draft Preparation, Z.P. and M.F.; Writing - Review \& Editing, Z.P. and M.F. Both authors have read and agreed to the published version of the manuscript.

Funding: This research was funded by the Slovak Research and Development Agency under contract no. APVV18-0103: Paradigmatic Changes in the Understanding of Universe and Man from Philosophical, Theological, and Physical Perspectives.

Institutional Review Board Statement: Not applicable.

Conflicts of Interest: The founding sponsors had no role in the design of the study; in the writing of the manuscript, and in the decision to publish the results.

\section{References}

Aristotle. 2000. Nicomachean Ethics. Translated by Roger Crisp. Cambridge: Cambridge University Press.

Cottingham, John. 2003. On the Meaning of Life. New York: Routledge.

Cottingham, John. 2005. The Spiritual Dimension: Religion, Philosophy and Human Value. Cambridge: Cambridge University Press.
Earp, D. Brian, and Julian Savulescu. 2020. Love drugs. The Chemical Future of Relationships. Stanford: Redwood Press.

Frey, S. Bruno. 2018. Economics of Happiness. Cham: Springer.

Epicurus. 2013. The Art of Happiness. Translated by George K. Strodach. New York: Penguin Group.

Frankl, E. Viktor. 1992. "Vôla k zmyslu." [Will to meaning]. Filozofia 47 (11): 680-685.

Hughes, James. 2004. Citizen Cyborg, Why Democratic Societies Must Respond to the Redesigned Human of the Future. Cambridge: Westview Press.

Hughes, James. 2011. "After Happiness, Cyborg Virtue." Free Inquiry 32 (1): 34-37.

Huxley, Aldous. 1932. Brave New World. London: Chatto \& Windus.

Martin, W. Mike. 2008. "Paradoxes of happiness." Journal of Happiness Studies 9 (2): 171-184.

Metz, Thaddeus. 2013. Meaning in life. An Analytic Study. Oxford: Oxford University Press.

Pearce, David. 1998. The Hedonistic Imperative. Accessed: August 15, 2021. https://www.hedweb. com/hedab.htm.

Pojman, P. Louis, and James Fieser. 2011. Ethics: Discovering Right and Wrong. Boston, MA: Wadsworth.

Seligman, E. Martin and Mihaly Csikszentmihalyi. 2000. "Positive Psychology: An introduction." American Psychologist 55 (1): 5-14.

Seligman, E. Martin. 2011. Flourish. New York: Free Press.

Teilhard de Chardin, Pierre. 1973. "Réflexions sur le Bonheur" (manuscript from 1943). In Les Directions de l'Avenir (Ouevres XI.). Paris: Éditions du Seuil, 119-140.

Walker, Mark. 2007. "Happy-people-pills and prosocial behaviour." Philosophica 79(1): 93-111.

Walker, Mark. 2013. Happy-People-Pills for All. New York: John Wiley \& Sons Inc. 